\title{
Tingkat Keberhasilan Program Gertak Berahi Inseminasi Buatan di Provinsi Sulawesi Tengah
}

\section{(Level of Succes on Syncronized Estrus Artificial Insemination Program in Province of Central Sulawesi)}

\author{
Affandhy $\mathrm{L}^{1}$, Gultom $\mathrm{AR}^{2}$, Aryogi ${ }^{1}$ \\ ${ }^{1}$ Loka Penelitian Sapi Potong, Jl. Pahlawan No. 2, Grati, Pasuruan, Jawa Timur \\ ${ }^{2}$ Direktorat Jenderal Peternakan dan Kesehatan Hewan, Kementerian Pertanian \\ lukmansingosari@gmail.com
}

\begin{abstract}
Gertak Berahi dan Inseminasi Buatan (GBIB) programme was expected to support national self-sufficiency in beef. This study aims to evaluate level of succesness on GBIB Program in Central Sulawesi. Research was conducted with periodicly survey and interview using questionnaire by random sampling respondent. The parameters were the number of cattles selected (target and actual), as acceptors, injection of PGF2 $\alpha$, and response of respondents. Data were analyzed descriptively. The results showed that realization of the actual injection of PGF $2 \alpha$ and AI were lowest in the district Poso and Toli-Toli.The highest realization of GBIB activity was in District of Bangkep and Kota Palu; While the realiasation of GBIB activities in accordance with the target or near the target was in District of Banggai, Morowali, North Morowali, Buol and less than target, were District of Tojo Una-Una, Donggala, Sigi, and Parigi Mautoring. Response GBIB implementation activities at the district of Central Sulawesi were very good, as shown by their procurement processes, socialization, coordination and good response of farmer acceptor, but the achievements of realization are still lacking, especially injection PGF2 $\alpha$ and $\mathrm{AI}^{2 \text { th }}$. Issues program GBIB includes shortage additional medical personnel, AI, pregnancy examinations and facilities infrastructures. It was concluded that the GBIB program in Central Sulawesi Province was quite successful, as the realization was in line with the target.
\end{abstract}

Key Words: Response, Respondent, GBIB Program

\begin{abstract}
ABSTRAK
Program Gertak Berahi dan Inseminasi Buatan (GBIB), diharapkan dapat mendukung swasembada daging sapi nasional. Penelitian ini bertujuan untuk mengetahui tingkat keberhasilan program GBIB di Provinsi Sulawesi Tengah. Penelitian dilakukan secara survei berkala, wawancara menggunakan kuesioner dan random sampling terhadap petugas dinas dan peternak di kabupaten/kota di Provinsi Sulawesi Tengah. Parameter meliputi jumlah sapi terseleksi (terget dan realisasi), akseptor Inseminasi Buatan (IB), jumlah penyuntikan hormon PGF2 $\alpha$ dan respon responden. Data dianalisis secara deskriptif. Hasil penelitian menunjukkan bahwa realisasi injeksi PGF2 $\alpha$ dan IB terendah di Kabupaten Poso dan Toli-Toli, realisasi kegiatan GBIB yang tertinggi di wilayah Kabupaten Bangkep dan Kota Palu, sesuai dengan target atau mendekati target di Kabupaten Banggai, Morowali, Morowali Utara, Buol dan kurang dari target di Kabupaten Tojo Una-Una, Donggala, Sigi dan Parigi. Respon kegiatan pelaksanaan GBIB di kabupaten/kota di Provinsi Sulawesi Tengah sangat baik. Hal ini ditunjukkan dengan adanya proses pengadaan, sosialisasi dan koordinasi yang lancar serta respon peternak menyediakan akseptor yang cukup, namun capaian realisasi masih kurang terutama injeksi PGF2 $\alpha$ dan IB kedua. Permasalahan program GBIB meliputi kekurangan penambahan tenaga medis, IB, ATR, PKB dan sarana prasaran (transportasi, $\mathrm{N}_{2}$ cair, software format laporan). Disimpulkan bahwa program GBIB di Provinsi Sulawesi Tengah cukup berhasil, karena realisasinya sesuai/mendekati target.
\end{abstract}

Kata Kunci: Respon, Responden, Program GBIB 


\section{PENDAHULUAN}

Usaha pembibitan sapi potong sebagai pemasok utama sapi bakalan dalam negeri, sebagian besar merupakan usaha peternakan rakyat dengan skala pemeliharaan 2-5 ekor (Alam et al. 2014; Riszqina et al. 2011), sehingga produktivitasnya belum memberikan peningkatan pendapatan dan kesejahteraan yang signifikan bagi petani-peternak. Peningkatan produktivitas sapi potong tersebut dapat dilakukan melalui penyediaan sapi bakalan dengan tingkat kelahiran secara serentak atau bersamaan. Keberhasilan terjadinya kelahiran secara bersama-sama juga ditentukan oleh kemampuan sapi betina menghasilkan jumlah corpus luteum dalam satu siklus reproduksi. Sinkronisasi estrus maupun ovulasi dengan memanfaatkan hormon reproduksi, melalui program "Gertak Berahi dan Inseminasi Buatan" (GBIB) oleh Direktur Pembibitan dan Budidaya Ternak, Direktorat Jenderal Peternakan dan Kesehatan Hewan Kementerian Pertanian (Ditjen PKH 2015) diharapkan dapat mendukung swasembada daging sapi nasional yang merupakan salah satu program NAWACITA Presiden RI, yaitu peningkatan UPSUS daging sapi program utama Kementerian Pertanian.

Sasaran kegiatan GBIB secara nasional adalah: (1) Terlaksananya sikronisasi berahi sebanyak 691.000 ekor, (2) Tertanganinya kasus gangguan reproduksi sebanyak 300.000 ekor, (3) Tercapainya kelahiran sapi/kerbau tahun 2016 sebanyak 2.096.846 ekor (GBIB 518.250 ekor dan IB reguler 1.578 .596 ekor), melalui penggunaan teknologi sinkronisasi berahi pada sapi dan kerbau berupa dua kali penyuntikan PGF2 $\alpha$ (hari ke 1 dan 11); selanjutnya dilakukan IB pada hari 12-15 dari suntikan pertama. Sebelum melakukan injeksi hormon, dilakukan pemeriksaan organ reproduksi dengan siklus berahi normal (Ditjen PKH 2015). Target GBIB di Provinsi Sulteng adalah target akseptor IB dan pemberian hormon PGF2 $\alpha$ sebanyak 21.000 ekor (Dinas Peternakan dan Kesehatan Hewan Prov. Sulteng, 2015).

Teknik penggunaan hormon PGF2 $\alpha$ pada sapi dapat dilakukan melalui beberapa metode sinkronisasi, antara lain superovulasi (Situmorang \& Triwulaningsih 2004; Adriani et al. 2007), sinkronisasi estrus (Ditjen PKH 2015) dan sinkronisasi ovulasi (Affandhy et al. 2015; Ratnawati \& Affandhy, 2009). Sinkronisasi estrus dapat dilakukan apabila sapi induk memiliki organ reproduksi dan siklus reproduksi normal, sedangkan sinkronisasi ovulasi digunakan pada sapi-sapi induk/betina yang tidak normal (hypofungsi ovari, atropi/ovari mengecil). Perlu diketahui bahwa ternak yang mengalami estrus belum tentu terjadi ovulasi, namun apabila ternak mengalami ovulasi dipastikan mengalami gejala berahi. Gejala berahi ternak ditandai dengan warna vulva kemerahan, bengkak dan keluar lendir serta manaiki sesama ternak (Affandhy et al. 2007; Affandhy et al. 2014).

Superovulasi juga dapat digunakan untuk mendukung peningkatan populasi pada program GBIB. Superovulasi dapat menggunakan hormon Pregnant Mare's Serum Gonadotrophin (PMSG), Follikel Simulaing Hormone (FSH) dan Human Menopouse Gonadotrophin (HMG). Superovulasi secara intramuskuler dengan hormon FSH pada dosis $40 \mathrm{mg}$, FSH secara intramuskuler memberikan hasil terbaik dengan menghasilkan jumlah corpus luteum terbanyak (Adriani et al. 2007). Penggunaan kombinasi hormon GnRH, PGF dan FSH untuk program superovulasi, rata-rata menghasilkan kebuntingan sapi 61\%; dengan skor kondisi tubuh dan gizi pakan sapi kurang baik (Prihandini et al. 2010); demikian pula hasil penelitian Ratnawati et al. (2011) menyatakan bahwa penggunakan PMSG impor dosis 1000 IU menghasilkan jumlah corpus luteum (CL) dan tingkat kebuntingan lebih baik dibandingkan dengan hormon PMSG lokal, yaitu CL berjumlah 1-2 buah (PMSG impor dan 1 buah PMSG lokal). Hardini et al. (2011) menyatakan bahwa pemberian hormon PMSG pada sapi dengan perbaikan pakan berpeluang menghasilkan CL lebih dari dua. 
Penelitian ini bertujuan untuk mengetahui tingkat keberhasilan program GBIB di kabupaten/kota Provinsi Sulteng.

\section{MATERI DAN METODE}

Pelaksanaan kegiatan penelitian berupa survei secara berkala di tingkat provinsi dan kabupaten di Provinsi Sulteng pada tahun anggaran 2015 selama tiga bulan, yaitu pada September, Oktober dan November 2015. Guna mengetahui realisasi, respon dan permasalahan program GBIB, dilakukan wawancara dengan cara pengisian kuisioner terhadap petugas dinas dan wawancara ke peternak yang terlibat dalam pelaksanaaan program GBIB di beberapa kabupaten di Provinsi Sulteng.

Pengambilan sampel data dilakukan secara random sampling sebanyak 5-10 orang peternak dari dua kelompok peternak. Kelompok peternak yang diwawancarai diambil dari 3 (tiga) kabupaten, yaitu Kabupaten Sigi, Kabupaten Donggala, dan Kota Palu. Sedangkan responden petugas yang diwawancarai sebanyak dua orang dari 12 kabupaten/kota, yaitu di Kabupaten/Kota Banggai, Bangkep, Tojo Una-Una, Donggala, Sigi, Kota Palu, Parigi Mautong, Poso, Morowali, Morowali Utara, Toli-Toli dan Buol.

Data yang dikumpulkan berupa rekapitulasi pelaksanaan GBIB di tingkat Kabupaten/Kota Provinsi Sulteng tahun anggaran 2015, meliputi jumlah petugas, jumlah sapi terseleksi (target dan realisasi), akseptor GBIB, jumlah penyuntikan hormon PGF2 $\alpha$, serta jumlah sapi yang di IB. Selanjutnya dilakukan pengisian kuisioner meliputi data umum (nama, alamat, nama dinas, nomor email dan telepon), pencatatan data kelengkapan sarana-prasarana GBIB termasuk kesesuaian proses pengadaan, ketersediaan akseptor GBIB, proses kelancaran koordinasi pelaksanaan dan sosialisasi GBIB di tingkat provinsi dan peternak oleh Dinas Peternakan dan Kesehatan Hewan Provinsi Sulteng dan BBIB Lembang. Data lainnya yang dikumpulkan, yaitu yang berhubungan dengan pelaksanaan GBIB di Sulteng meliputi jumlah akseptor yang diinjeksi PGF2 $\alpha$ ke-1 dan ke-2 dan jumlah akseptor yang di IB ke-1 dan ke-2, jumlah dan keterampilan petugas di lapang, jumlah petugas ATR, PKB, inseminator, rekorder, permasalahan-permasalahan dan solusi kebijakan berupa strategi tindak lanjut perbaikan program penanganan GBIB di masa yang akan datang dalam rangka keberlanjutan program GBIB tahun anggaran 2016.

Data dianalisis secara deskriptif berupa rekapitulasi hasil isian kuisioner dan wawancara langsung dengan petugas atau kelompok ternak dalam bentuk tabel dan atau grafik histogram.

\section{HASIL DAN PEMBAHASAN}

\section{Pelaksanaaan GBIB di Provinsi Sulawesi Tengah}

Hasil rekapitulasi realisasi pelaksanaan GBIB di seluruh kabupatan/kota Provinsi Sulawesi Tengah tahun anggaran 2015, disajikan pada Gambar 1.

Tampak bahwa pelaksanaan kegiatan GBIB di wilayah kabupaten/kota Prov. Sulteng, Kab. Poso dan Toli-Toli memiliki realisasi injeksi PGF2 $\alpha$ dan IB terendah dibandingkan dengan wilayah kabupaten lain (Gambar 1). Hal ini disebabkan antara lain karena: (1) realisasi ke tingkat Provinsi Sulteng atau Dinas PKH Provinsi Sulteng belum dilaporkan, (2) Kab. Poso dan Toli-Toli merupakan wilayah dengan topografinya berbukit dan jauh dari Prov. Sulteng (Sulawesi Tengah Dalam Angka 2015). Realisasi kegiatan GBIB yang tertinggi terdapat di wilayah Kab. Bangkep dan Kota Palu (Gambar 1 dan Tabel 1), sedangkan realiasasi kegiatan GBIB yang sesuai/mendekati target adalah di Kab. Banggai, 
Morowali, Morowali Utara, dan kurang dari target yaitu Buol, Tojo Una-Una, Donggala, Sigi, Parigi, Mautoring, Toli-toli dan Poso (Tabel 1).

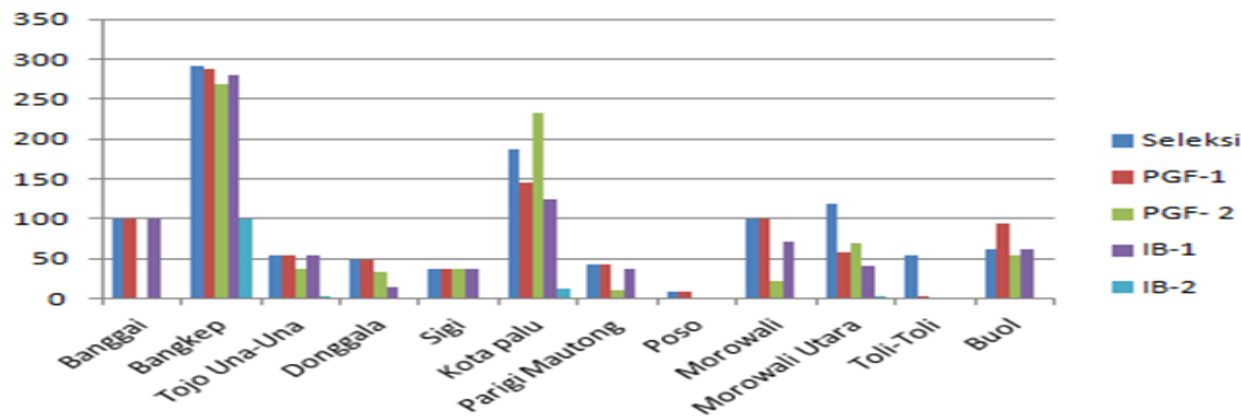

Gambar 1. Presentase realisasi seleksi akseptor, injeksi PGF2 $\alpha$ ke-1 dan PGF2 $\alpha$ ke-2, IB ke-1 dan IB ke-2 di kabupaten/kota Provinsi Sulawesi Tengah

Tabel 1. Target dan realisasi jumlah sapi terseleksi dan injeksi PGF2 $\alpha$ di kabupaten/kota Provinsi Sulawesi Tengah

\begin{tabular}{lrrrrrrrrr}
\hline \multirow{2}{*}{ Kabupaten/Kota } & \multicolumn{3}{c}{ Jumlah Seleksi } & \multicolumn{3}{c}{ Jumlah Injeksi Hormon } & \multicolumn{3}{c}{ Jumlah Injeksi Hormon } \\
& \multicolumn{1}{c}{ A } & \multicolumn{1}{c}{$\mathrm{B}$} & \multicolumn{1}{c}{$\%$} & \multicolumn{1}{c}{$\mathrm{A}$} & \multicolumn{1}{c}{$\mathrm{B}$} & \multicolumn{1}{c}{$\%$} & \multicolumn{1}{c}{ A } & B & \multicolumn{1}{c}{$\%$} \\
\cline { 2 - 10 } Banggai & 5.000 & 4.981 & 99,6 & 5.000 & 4.981 & 99,6 & 2.500 & - & 0,0 \\
Bangkep & 200 & 582 & 291,0 & 200 & 577 & 288,5 & 100 & 269 & 269 \\
Tojo Una-Una & 1.500 & 822 & 54,8 & 1.500 & 800 & 53,3 & 750 & 283 & 37,7 \\
Donggala & 3.000 & 1.442 & 48,1 & 3.000 & 1.442 & 48,1 & 1.500 & 506 & 33,7 \\
Sigi & 3.000 & 1.119 & 37,3 & 3.000 & 1.119 & 37,3 & 1.500 & 562 & 37,5 \\
Kota Palu & 200 & 373 & 186,5 & 200 & 289 & 144,5 & 100 & 233 & 233 \\
Parigi Mautong & 3.000 & 1.270 & 42,3 & 3.000 & 1.270 & 42,3 & 3.000 & 303 & 10,1 \\
Poso & 1.000 & 74 & 7,4 & 1.000 & 74 & 7,4 & 500 & - & 0,0 \\
Morowali & 1.000 & 1.000 & 100 & 1.000 & 1.000 & 100 & 500 & 110 & 22 \\
Morowali Utara & 1.100 & 1.311 & 119,2 & 1.100 & 627 & 57,0 & 550 & 384 & 69,8 \\
Toli-Toli & 1.000 & 531 & 53,1 & 1.000 & 35 & 3,5 & 500 & - & 0,0 \\
Buol & 1.000 & 629 & 62,5 & 1.000 & 938 & 93,8 & 500 & 266 & 53,2 \\
\hline Jumlah & 21.000 & 14.812 & 67,3 & 21.000 & 13.152 & 62,63 & 12.000 & 2.916 & 24,3 \\
\hline
\end{tabular}

A: Target; B: Realisasi

Tingginya realisasi GBIB terutama di Kabupaten Bangkep dan Kota Palu, diduga karena sumber pakan yang cukup menyebabkan skor kondisi tubuh (SKT) sapi induknya lebih baik (Gambar 1), sehingga sinkronisasi berahi menggunakan hormon PGF2 $\alpha$ bisa dilakukan. Berbeda halnya dengan kondisi sapi yang pakannya kurang seperti di Kabupaten Donggala (Gambar 2), perlu penambahan pakan sebelum dilakukan program sinkronisasi estrus dan ovulasi. Ratnawati et al. (2015) menyatakan, sapi induk PO dengan SKT $\geq 6$ (skala 1-9) yang disinkronisasi kombinasi hormon GnRH dan Prostaglandin, menunjukkan respon berahi sebesar 85,7\%; sedangkan jika menggunakan kombinasi hormon GnRH, PGF dan FSH untuk program superovulasi, menghasilkan rata-rata kebuntingan $61 \%$ untuk skor kondisi tubuh dan gizi pakan sapi kurang baik (Prihandini et al. 2010). Faktor genetik, umur dan kondisi tubuh induk, mempengaruhi jumlah ternak yang estrus sebagai respon sinkronisasi estrus. Oleh karena itu, kondisi tubuh sapi 
induk/betina yang sedang hingga gemuk merupakan prasyarat untuk mendapatkan respon estrus yang tinggi (Praharani 2011).

Data kebuntingan bulan November belum dilaporkan, karena IB baru dilakukan kurang dari 2 bulan sebelumnya. Hasil laporan monitoring BBIB Lembang bulan September menunjukkan, kabupaten Banggai dengan jumlah akseptor 6.000 ekor diperkirakan jumlah kebuntingannya 4.398 ekor (73,30\%) (Anonimus 2015). Oleh karena itu, sinkronisasi yang paling baik adalah menggunakan program ovsynch (kombinasi hormon PGF2 $\alpha$ dan GnRH) seperti yang dilaporkan oleh Putro \& Kusumawati (2014), yaitu dinamika folikel ovulasi setelah sinkronisasi estrus dengan prostaglandin PGF2 $\alpha$ menjadi lebih sinergi dengan penambahan GnRH atau menggunakan hormon PGF2 $\alpha$ dengan lebih dari satu kali menyuntikan; serta seperti hasil penelitian Sariubang \& Nurhayu (2011), yang menyatakan bahwa penyuntikan 3 ml PGF2 $\alpha$ dilakukan sebanyak dua kali selang 11 hari dari penyuntikan pertama, memberikan respon berahi induk sapi Bali lebih baik dibandingkan dengan penyuntikan $\mathrm{PGF}_{2 \alpha}$ satu kali.
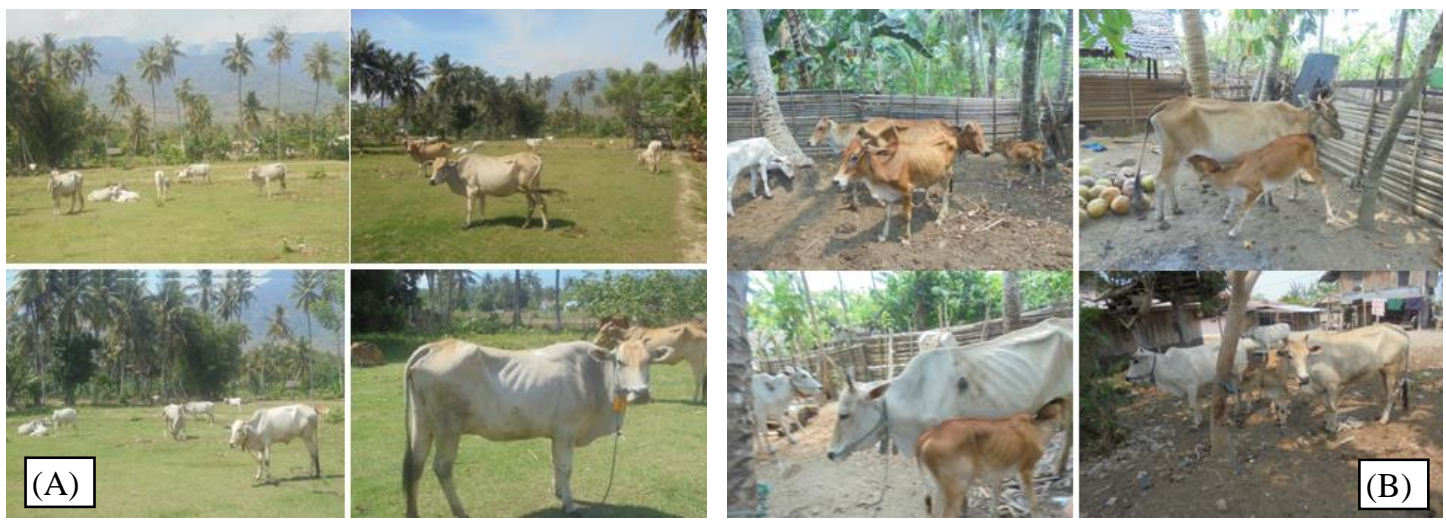

Gambar 2. Kondisi sapi, (A) Di Kabupaten Palu; (B) Kabupaten Donggala dan Sigi

\section{Respon pelaksanaan GBIB}

Respon kegiatan pelaksanaan GBIB di wilayah kabupaten/kota Prov. Sulawesi Tengah sangat baik. Hal ini ditunjukkan dengan adanya proses pengadaan berjalan lancar, sosialisasi dilaksanakan sesuai jadwal pelaksanaan, peternak sangat antusias, koordinasi lancar dan ketersedian akseptor cukup (Gambar 3). Namun respon yang masih kurang adalah capaian realisasi penyuntikan $\mathrm{PFG}_{2 \alpha}$ dan IB yang kemungkinan belum dilaporkan ke Dinas PKH Provinsi Sulawesi Tengah.

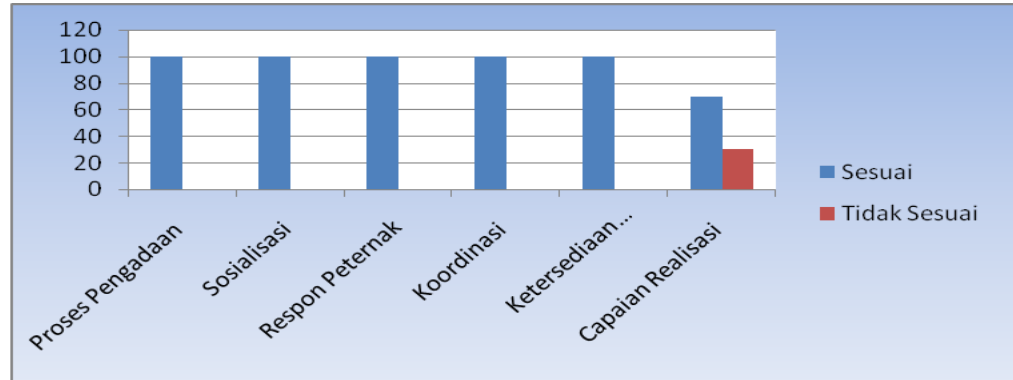

Gambar 3. Persentase respon kegiatan pelaksanaan GBIB di wilayah kabupaten dan kota Provinsi Sulawesi Tengah 
Tabel. 2. Realisasi kegiatan sinkronisasi dan IB di setiap kabupaten/kota Provinsi Sulteng

\begin{tabular}{lcccc}
\hline \multirow{2}{*}{ Kabupaten/kota } & Seleksi & Sinkronisasi & IB-I & IB-II \\
\cline { 2 - 5 } & \multicolumn{3}{c}{ ekor } \\
\hline Banggai & 5.000 & 4.981 & 4.981 & 0 \\
Bangkep & 200 & 846 & 559 & 54 \\
Tojo Una-Una & 1.500 & 1.083 & 800 & 5 \\
Donggala & 3.000 & 1.948 & 438 & 0 \\
Sigi & 3.000 & 1.681 & 1.097 & 0 \\
Kota Palu & 200 & 522 & 250 & 13 \\
Parigi Mautong & 3.000 & 1.573 & 1.120 & 0 \\
Poso & 1.000 & 74 & 0 & 0 \\
Morowali & 1.000 & 1.110 & 708 & 0 \\
Morowali Utara & 1.100 & 1.011 & 445 & 10 \\
Toli-Toli & 1.000 & 35 & 0 & 0 \\
Buol & 1.000 & 846 & 629 & 0 \\
\hline Jumlah & 21.000 & 15.710 & 11.027 & 82 \\
\hline
\end{tabular}

Sumber: Dinas Peternakan dan Kesehatan Provinsi Sulteng (2015)

Salah satu contoh pelaksanaan kegiatan GBIB yang melebihi target adalah di Kabupaten Bangkep dan Kota Palu (Tabel 1), namun dalam pelaksanaannya masih menghadapi beberapa permasalahan, seperti keterlambatan peternak melaporkan tanda berahi ternaknya ke petugas lapang, sehingga waktu pelaksanaan IB terlambat (karena setelah diinjeksi hormon PFG2 $\alpha$, ternaknya masih di lokasi pengembalaan), yaitu ditunda sampai malam hari atau tidak terjadi kebuntingan (Dinas Pertanian, Peternakan dan Kelautan Kota Palu, 2015).

Beberapa petugas dan peternak sudah berpengamalam dalam mengamati tanda berahi dan ovulasi sapi, bahkan termasuk pemahaman bahwa sapi yang mengalami estrus belum tentu terjadi ovulasi, namun apabila ternak mengalami ovulasi dipastikan mengalami gejala berahi. Gejala berahi ternak ditandai dengan warna vulva kemerahan, bengkak dan keluar lendir serta menaiki sesama ternak (Affandhy et al. 2007; 2014). Faktor lain yang lebih penting dalam sinkronisasi estrus dan keberhasilan IB adalah kondisi reproduksi sapi betina resipien, kualitas semen beku, ketepatan deteksi estrus, keterampilan inseminator dalam iseminasi dan handling semen beku (Sianturi et al. 2010).

Salah satu permasalahan program GBIB adalah kekurangan tenaga medis, IB, ATR, PKB dan sarana prasaran (transportasi, $\mathrm{N}_{2}$ cair, software format laporan). Disarankan sapi resipien yang digunakan untuk sinkronisasi estrus ataupun ovulasi, mempunyai skor kondisi tubuh baik (>6 pada skala 1-9) (Ratnawati et al. 2015) dan dapat dilakukan penambahan nutrien pakan basalnya sebelum menyuntikan hormon PGF2 $\alpha$ (Prihandini et al. 2010).

\section{KESIMPULAN}

Realisasi program Gertak Berahi Inseminasi Buatan (GBIB) di Sulawesi Tengah dilaksanakan cukup baik dan tertinggi terdapat di wilayah Kab. Bangkep dan Kota Palu dengan tingkat persentase jumlah injeksi hormon PGF2 $\alpha$ ke satu dan kedua berturut turut di kedua lokasi tersebut 288,5 dan 144,5\% serta yang kedua sebesar 269 dan $233 \%$. 
Pelaksanaan program GBIB di Provinsi Sulawesi Tengah menunjukkan hasil positif dan tingkat keberhasilannya telah mendekati target.

\section{UCAPAN TERIMA KASIH}

Ucapan terima kasih ditujukan kepada kepala dinas peternakan dan kesehatan hewan tingkat kabupaten/kota maupun Provinsi Sulawesi Tengah serta Direktorat Jenderal Peternakan dan Kesehatan Hewan, Kementerian Pertanian maupun staf Loka Penelitian Sapi Potong yang telah memberikan bantuan dana penelitian serta semua pihak yang mendukung selama pelaksanaan kegiatan penelitian berlangsung.

\section{DAFTAR PUSTAKA}

Adriani, Depison, Rosadi B, Supriondo Y, Isroli. 2007. Pengaruh Superovulasi Terhadap Jumlah Corpus. J Indon Trop Anim Agric. 32:207-212.

Alam A, Dwijatmiko S, Sumekar W. 2014. Faktor-Faktor Yang Mempengaruhi Aktivitas Budidaya Ternak Sapi Potong di Kabupaten Buru. Agrinimal. 4:28-37.

Affandhy L, Dikman DM, Aryogi. 2007. Petunjuk teknis manajemen perkawinan sapi potong. Bogor (Indonesia): Pusat Penelitian dan Pengembangan Peternakan. $43 \mathrm{hlm}$.

Affandhy L, Aryogi, Bess Tiesnamurti. 2014. Perkawinan Sapi Potong di Indonesia. Jakarta (Indonesia): IAARD Press.

Affandhy L, Dikman DM, Widyaningrum Y. 2015. The response of gonadotropin hormone at different dosage on time of oestrus, the profile of progesterone, estrogen and corpus luteum of ongole crossed cows. Proceedings of The 6th ISTAP International Seminar on Tropical Animal Production. Part II: 550-553. Yogyakara (Indonesia): Gadjah Mada University.

Anonimus. 2015. Peran Gertak Berahi dan Optimalisasi IB (BGIB) bagi penambahan populasi di Kabupaten Banggai Provinsi Sulawesi Tengah. Laporan BBIB Monitoring Lembang bulan September 2015. (http://banksperma.com/alpha/)

Direktorat Pembibitan Ternak, Ditjen PKH. 2015. Pedoman Teknis Percepatan Peningkatan Populasi melalui Gertak/Sinkronisasi Berahi dan Optimalisasi Inseminasi Buatan (IB) serta Penaggulangan Gangguan Reproduksi pada Ternak Sapi dan Atau Kerbau. APBN-P Tahun 2015. Ditjen PKH. 44 halaman.

Hardini D, Mualif A, Riyanto. 2011. Perbaikan pakan dan penggunaan hormon pada sapi induk untuk menghasilkan pedet kembar di Jawa Timur. Dalam: Prasetyo LH, Damayanti R, Iskandar S, Herawati T, Priyanto D, Puastuti W, Anggraeni A, Tarigan S, Wardhana AH, Dharmayanti NLPI, penyunting. Teknologi peternakan dan veteriner untuk peningkatan produksi dan antisipatif terhadap dampak perubahan iklim. Prosiding Seminar Nasional Teknologi Peternakan dan Veteriner. Bogor, 7-8 Juni 2011. Bogor (Indonesia): Puslitbang Peternakan. hlm. 121-128.

Dinas PKH Provinsi Sulteng. 2015. Target dan Realisasi kegiatan GBIB bulan Oktober dan November 2015 Dinas Peternakan dan Kesehatan Hewan Provinsi Sulteng. (Laporan November 2015).

Dinas Pertanian, Peternakan dan Kelautan Kota Palu Provinsi Sulteng. 2015. Laporan populasi ternak sapi dan luas lahan pertanian Kota Palu Prov. Sulteng (Laporan November 2015).

Praharani L. 2011. Respon sinkronisasi estrus sapi brahman dan persilangannnya. Dalam: Prasetyo LH, Damayanti R, Iskandar S, Herawati T, Priyanto D, Puastuti W, Anggraeni A, Tarigan S, Wardhana AH, Dharmayanti NLPI, penyunting. Teknologi peternakan dan veteriner untuk peningkatan produksi dan antisipatif terhadap dampak perubahan iklim. Prosiding Seminar 
Nasional Teknologi Peternakan dan Veteriner. Bogor, 7-8 Juni 2011. Bogor (Indonesia): Puslitbang Peternakan. hlm. 68-74.

Prihandini PW, Efendy J, Ratnawati D, Sulistya TA. 2010. Pengaruh skor kondisi tubuh (4-7) pada tiga level pemberian FSH untuk meningkatkan kelahiran kembar $>40 \%$ dan tingkat kebuntingan induk $>70 \%$ pada Sapi PO. Laporan Kegiatan Penelitian Program Insentif Riset Terapan. Lolitsapi.

Putro PP, A. Kusumawati. 2014. Dinamika Folikel ovulasi setelah singkronisasi estrus dengan Prostaglandin F2 $\alpha$ pada sapi perah. J Sain Vet. 32:22-31.

Ratnawati D, Affandhy L. 2009. Implemantasi sinkronisasi ovulasi menggunakan Gonadrotropin Realising Hormon (GnRH) dan Prostaglandin (PGF2 $\alpha$ ) pada induk sapi Bali. Dalam: Sani Y, Natalia L, Brahmantyo B, Puastuti W, Sartika T, Nurhayati, Anggraeni A, Matondang RH, Martindah E, Estuningsih SE, penyunting. Teknologi peternakan dan veteriner untuk meningkatkan ketahanan pangan dan kesejahteraan peternak. Prosiding Seminar Nasional Teknologi Peternakan dan Veteriner. Bogor, 13-14 Agustus 2009. Bogor (Indonesia): Puslitbang Peternakan. hlm. 72-76.

Ratnawati D, Dikman DM, Efendy J. 2011. Pemanfaatan PMSG lokal sebagai alternatif hormon superovulasi. Dalam: Prasetyo LH, Damayanti R, Iskandar S, Herawati T, Priyanto D, Puastuti W, Anggraeni A, Tarigan S, Wardhana AH, Dharmayanti NLPI, penyunting. Teknologi peternakan dan veteriner untuk peningkatan produksi dan antisipatif terhadap dampak perubahan iklim. Prosiding Seminar Nasional Teknologi Peternakan dan Veteriner. Bogor, 7-8 Juni 2011. Bogor (Indonesia): Puslitbang Peternakan. hlm. 32-37.

Ratnawati D, Adinata Y, Luthfi M. 2015. Respon sinkronisasi berahi pada induk sapi potong dengan skor kondisi tubuh berbeda pada peternakan rakyat. Dalam: Noor MN, Handiwirawan E, Martindah E, Widiastuti R, Sianturi RSG, Herawati T, Purba M, Anggraeny YN, Batubara A, penyunting. Teknologi Peternakan dan Veteriner untuk Peningkatan Daya Saing dan Mewujudkan Kedaulatan Pangan Hewani. Prosiding Seminar Nasional Teknologi Peternakan dan Veteriner. Jakarta, 8-9 Oktober 2015. Jakarta (Indonesia): IAARD Press. hlm. 74-80.

Jannah RL, Isbandi, Rianto E, Santoso SI. 2011. Analisis pendapatan peternak sapi potong dan sapi bakalan kerapan di Pulau Sapudi Kabupaten Sumenep. JITP 1:188-192.

Sariubang M, Nurhayu A. 2011. Respon penyuntikan hormon Capriglandin (PGF2 $\alpha$ ) terhadap sinkronisasi berahi induk sapi Bali di Kabupaten Bantaeng Sulawesi Selatan. Dalam: Prasetyo LH, Damayanti R, Iskandar S, Herawati T, Priyanto D, Puastuti W, Anggraeni A, Tarigan S, Wardhana AH, Dharmayanti NLPI, penyunting. Teknologi peternakan dan veteriner untuk peningkatan produksi dan antisipatif terhadap dampak perubahan iklim. Prosiding Seminar Nasional Teknologi Peternakan dan Veteriner. Bogor, 7-8 Juni 2011. Bogor (Indonesia): Puslitbang Peternakan. hlm. 74-80.

Sianturi RG, Kusumaningrum DA, Adiati U, Triwulaningsih E, Situmorang P. 2010. Efektifitas beberapa metode sinkronisasi estrus dan inseminasi buatan pada kerbau rawa di Banten. Seminar dan Lokakarya Nasional Kerbau :76-83.

Situmorang P, Triwulaningsih E. 2004. Aplikasi dan inovasi teknologi transfer embrio (TE) untuk pengembangan sapi potong. Prosiding Lokakarya Nasional Sapi Potong 2004. Balai Penelitian Ternak, Ciawi-Bogor.

BPS Sulteng. 2015. Sulawesi Tengah Dalam Angka. Badan Pusat Statisksik Provinsi Sulawesi Tengah. Bidang Integrasi Pengolahan dan Diseminasi Statistik. $504 \mathrm{hlm}$. 


\section{DISKUSI}

\section{Pertanyaan}

Pada kesimpulan perlu diperjelas, apakah menunjukkan hasil positif?

\section{Jawaban}

Belum bisa disimpulkan secara pasti masih akan ditambah data kuantitatif. Baru dari aspek persentase keberhasilan penerapannya. Hasil penerapan teknologi masih sedang diobservasi. 